Thorax (1967), 22, 21.

\title{
Functional results with aortic ball valve prostheses (Starr-Edwards) followed for two to three years
}

\author{
VIKING OLOV BJÖRK AND INGEMAR CULLHED \\ From the Departments of Thoracic Surgery and Internal Medicine, University Hospital, Uppsala, \\ Sweden
}

It is now believed that aortic insufficiency and calcific aortic stenosis must be treated with total valve replacement. Until recently this was performed with the aid of prostheses of teflon and similar materials. Even if the short-term results were promising, follow-up studies revealed a high percentage of breakdown of these prostheses (Björk, Cullhed, and Lodin, 1963 ; Larson and Kirklin, 1964). For the last three years we have used a ball valve prosthesis of the Starr and Edwards type (Björk, 1964). The aim of this paper is to report the 'long-term' clinical and haemodynamic results with this valve.

\section{MATERIAL}

Of the first 100 patients operated on with this technique, the first 20 survivors have been followed for between two and three years (see Table). There were four women and $16 \mathrm{men}$. The five oldest surviving patients were between 50 and 57 years old. The pre-operative heart size was increased in 17 patients. In cases 4 and 16 tight mitral stenosis was present and transventricular mitral dilatation had to be performed at the same operation as replacement of the aortic valve. In case 2 a single teflon cusp had been inserted one year before the total valve replacement, when this cusp was found to be fractured (case 1 in an earlier report by Björk et al., 1963).

\section{METHODS}

Our methods for the pre-operative clinical, haemodynamic, and angiocardiographic evaluation of aortic valve disease have recently been reported (Cullhed, 1964). Peroral anticoagulant therapy was begun post-operatively in all patients. The post-operative haemodynamic studies were made nine to 16 months after the operation. The peak systolic pressure gradient was measured between the left ventricle after transseptal catheterization and, in all cases except two, the central aorta after percutaneous catheterization of the brachial artery. Cardiac output was measured according to Fick's principle. Pressure and flow at rest and exercise was measured in the supine position. The physical working capacity in the sitting position was evaluated with the aid of a bicycle ergometer. As this test for several reasons often had to be stopped at a relatively low heart rate, the maximal physical working capacity (Wahlund, 1948) could not always be calculated. We therefore report the highest load at which the patient could work for 4 minutes. The heart rate on this load is also given. The presence of atrial fibrillation (cases 4 and 16) or second-degree atrioventricular block (case 3) limits the significance of the attained heart rates.

The radiological heart volume was calculated according to Jonsell (1939). With this method the heart volume in healthy adults seldom exceeds 450 $\mathrm{ml} . / \mathrm{m} .^{2}$ for women and $500 \mathrm{ml} . / \mathrm{m}^{2}$ for men. In the Table absolute as well as relative volumes are given.

\section{RESULTS}

MORTALITY In the first 50 operated patients there was an early mortality of $56 \%$. In the next 50 patients the mortality had decreased to $26 \%$. In the 20 patients reported here there have been three late deaths. Patient 5 died with sepsis one and a half years after the operation. Patient 8 , in spite of post-operative renal insufficiency, had made a good recovery and returned to full-time work when two years after the operation he died of an acute dissecting aortic aneurysm. Patient 16 made a slow recovery and died one and a half years after the operation from a coronary artery embolus.

HAEMODYNAMIC FINDINGS A basal systolic murmur of slight to moderate intensity was found in all patients at follow-up. In 10 patients left heart catheterization was performed (see Table and Figure). In most there was no gradient or only a small gradient at rest. During exercise, when the cardiac output increased to 13 to $151 . / \mathrm{min}$., the peak gradient rose to 35 to $55 \mathrm{~mm}$. $\mathrm{Hg}$. 
T A B L E

CLINICAL AND HAEMODYNAMIC FINDINGS

\begin{tabular}{|c|c|c|c|c|c|c|c|c|c|c|c|c|c|c|}
\hline \multirow{3}{*}{ Case } & \multirow{3}{*}{ Sex } & \multirow{3}{*}{ Age } & \multirow{3}{*}{ Pre-op. Diagnosis } & \multirow{3}{*}{$\begin{array}{l}\text { Starr } \\
\text { Pros- } \\
\text { thesis } \\
\text { No. }\end{array}$} & \multirow{2}{*}{\multicolumn{2}{|c|}{$\begin{array}{c}\text { Post-op. Aortic } \\
\text { Insufficiency }\end{array}$}} & \multicolumn{4}{|c|}{ Roentgenological Heart Volume } & \multicolumn{4}{|c|}{ Exercise Test } \\
\hline & & & & & & & \multicolumn{2}{|c|}{ Before } & \multicolumn{2}{|c|}{ After } & \multicolumn{2}{|c|}{ Before } & \multicolumn{2}{|c|}{ After } \\
\hline & & & & & $\underset{\text { mur- }}{\text { Mur- }}$ & $\begin{array}{l}\text { Aorto- } \\
\text { graphy }\end{array}$ & $\begin{array}{l}\text { Total } \\
\text { (ml.) }\end{array}$ & $\begin{array}{c}\text { Relative } \\
\left(\mathrm{ml} . / \mathrm{m} .^{2}\right)\end{array}$ & $\begin{array}{l}\text { Total } \\
\text { (ml.) }\end{array}$ & $\left|\begin{array}{l}\text { Relative } \\
\left(\mathrm{ml} . / \mathrm{m} .{ }^{2}\right)\end{array}\right|$ & $\underset{\text { min. }}{\operatorname{kpm} . /}$ & & $\begin{array}{c}\text { kpm./ } \\
\text { min. }\end{array}$ & $\begin{array}{l}\text { Heart } \\
\text { Rate }\end{array}$ \\
\hline 1 & $\mathbf{F}$ & 24 & $\begin{array}{l}\text { A.I. }+ \text { r } \\
\text { Valsalv }\end{array}$ & 12 & 0 & 0 & 1,260 & 800 & 700 & 440 & 150 & 124 & 600 & 176 \\
\hline $\begin{array}{r}2 \\
3 \\
4 \\
5 \\
6 \\
7 \\
8 \\
9 \\
10 \\
11 \\
12 \\
13 \\
14 \\
15 \\
16 \\
17 \\
18 \\
19 \\
20\end{array}$ & $\begin{array}{l}\mathbf{M} \\
\mathbf{M} \\
\mathbf{M} \\
\mathbf{M} \\
\mathbf{M} \\
\mathbf{M} \\
\mathbf{M} \\
\mathbf{M} \\
\mathbf{F} \\
\mathbf{M} \\
\mathbf{M} \\
\mathbf{M} \\
\mathbf{F} \\
\mathbf{M} \\
\mathbf{M} \\
\mathbf{M} \\
\mathbf{F} \\
\mathbf{M} \\
\mathbf{M}\end{array}$ & $\begin{array}{l}30 \\
43 \\
54 \\
54 \\
39 \\
28 \\
50 \\
56 \\
46 \\
42 \\
40 \\
27 \\
29 \\
34 \\
49 \\
57 \\
49 \\
40 \\
39\end{array}$ & $\begin{array}{l}\text { A.I. reoperated } \\
\text { A.I. } \\
\text { A.S. +A.I. + M.S. } \\
\text { A.S. + A.I. } \\
\text { A.S. + A.I. } \\
\text { A.S. + A.I. } \\
\text { A.I. } \\
\text { A.S. + A.I. } \\
\text { A.I. } \\
\text { A.I. } \\
\text { A.S. +A.I. } \\
\text { A.I. } \\
\text { A.I. } \\
\text { A.I. } \\
\text { A.S. + A.I. + M.S. } \\
\text { A.I. } \\
\text { A.I. } \\
\text { A.S. + A.I. } \\
\text { A.S.+A.I. }\end{array}$ & $\begin{array}{l}13 \\
13 \\
12 \\
13 \\
11 \\
13 \\
14 \\
12 \\
11 \\
13 \\
13 \\
11 \\
11 \\
12 \\
10 \\
12 \\
10 \\
9 \\
10\end{array}$ & $\begin{array}{l}0 \\
0 \\
0 \\
0 \\
0 \\
0 \\
0 \\
0 \\
0 \\
0 \\
2 \\
+ \\
2 \\
+ \\
+ \\
0 \\
0 \\
0 \\
+\end{array}$ & $\begin{array}{l}\overline{7} \\
\overline{0} \\
0 \\
0 \\
1 \\
\frac{1}{2} \\
1 \\
\frac{1}{1} \\
\frac{1}{4}\end{array}$ & $\begin{array}{r}1,100 \\
1,500 \\
1,240 \\
1,500 \\
760 \\
1,240 \\
1,470 \\
970 \\
900 \\
1,670 \\
980 \\
1,380 \\
1,020 \\
1,300 \\
1,160 \\
1,710 \\
1,830 \\
1,100 \\
730\end{array}$ & $\begin{array}{l}700 \\
890 \\
690 \\
735 \\
415 \\
640 \\
770 \\
510 \\
510 \\
740 \\
550 \\
735 \\
640 \\
625 \\
620 \\
790 \\
470 \\
680 \\
430\end{array}$ & $\begin{array}{r}920 \\
1,250 \\
1,110 \\
1,340 \\
630 \\
1,100 \\
1,130 \\
890 \\
730 \\
1,660 \\
1,140 \\
1,100 \\
690 \\
980 \\
1, \overline{300} \\
\frac{850}{1,030}\end{array}$ & $\begin{array}{l}575 \\
720 \\
590 \\
650 \\
320 \\
680 \\
600 \\
460 \\
440 \\
730 \\
580 \\
590 \\
430 \\
470 \\
\overline{640} \\
510 \\
\overline{610}\end{array}$ & $\begin{array}{l}600 \\
400 \\
350 \\
600 \\
600 \\
900 \\
600 \\
900 \\
300 \\
900 \\
600 \\
800 \\
300 \\
800 \\
500 \\
300 \\
250 \\
200 \\
400\end{array}$ & $\begin{array}{r}135 \\
132 \\
124 \\
110 \\
164 \\
154 \\
136 \\
162 \\
144 \\
175 \\
151 \\
182 \\
152 \\
160 \\
142 \\
92 \\
114 \\
110 \\
116\end{array}$ & $\begin{array}{l}300 \\
400 \\
400 \\
300 \\
600 \\
800 \\
600 \\
900 \\
300 \\
600 \\
600 \\
400 \\
450 \\
600 \\
= \\
450\end{array}$ & $\begin{array}{r}132 \\
80 \\
124 \\
134 \\
175 \\
162 \\
160 \\
185 \\
150 \\
162 \\
160 \\
161 \\
160 \\
158 \\
= \\
174 \\
128\end{array}$ \\
\hline
\end{tabular}

A.I. =aortic insufficiency ; M.S. =mitral stenosis; A.S. =aortic stenosis; $\mathbf{k p m . ~ = ~ k i l o p o n d m e t e r . ~}$

A high-pitched basal or mid-sternal diastolic murmur was found in six patients. This murmur was usually of low intensity and in two patients could be heard only in the sitting position at expiratory apnoea. Thoracic aortography was performed in 11 patients. There was no regurgitation in five patients, a slight regurgitation (grade 1 to 2 (Cullhed, 1964) ) in five patients, and severe aortic regurgitation in patient 20 . This man was reoperated on with a good primary result.

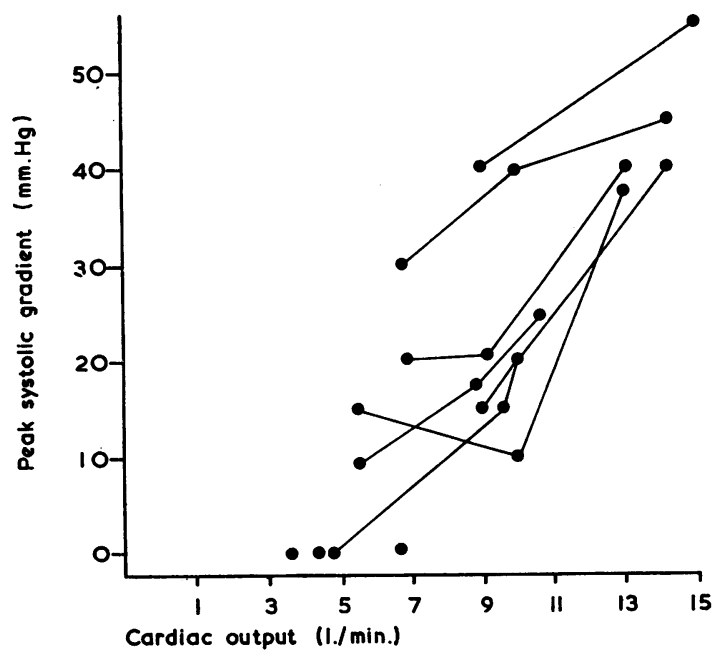

FIGURE. The systolic pressure gradient at different cardiac outputs over the Starr-Edwards ball valve prosthesis.
HEART SIZE At follow-up the heart volume was smaller in all but four patients. A decrease in relative heart volume of at least $10 \%$ of the preoperative volume was found in 11 patients, whereas an increase in excess of this percentage was noted only in patient 20 . In this patient, who had recurrent aortic insufficiency, the heart volume rapidly became normal after re-operation.

EXERCISE TEST In spite of differences in heart rate at the highest tolerated load in pre- and postoperative exercise tests, it can be seen from the $\dot{\sigma}$ Table that the working capacity was usually the 3 . same. A pronounced increase was noted in 8 patient 1, who was in left ventricular failure $₹$ before the operation. Three years later she works $ᄋ$ full time as a secretary. In patients 5,11 , and 13 a lower working capacity was noted. These patients were subjectively improved, and patient 13 had returned to full-time work.

SYSTEMIC THROMBO-EMBOLISM This was noted in two patients who were both operated on for mitral 0 stenosis as well and who had chronic atrial 0 fibrillation. In patient 4 the embolus became $\stackrel{\mathbb{D}}{\overparen{D}}$ lodged in the calf, resulting in only transient $\stackrel{\mathcal{D}}{?}$ ischaemic symptoms. He had discontinued the $\square$ prophylactic anticoagulant regimen, which was

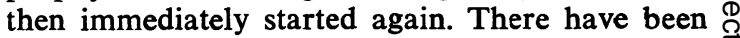
no more embolic episodes in this man. In patient $\mathbb{\mathbb { D }}$ 16 a coronary artery embolus was found at $\frac{\Omega}{0}$ necropsy. 
T A B L E-continued

\begin{tabular}{|c|c|c|c|c|c|c|c|}
\hline \multicolumn{6}{|c|}{ Post-op. Pressure-flow (Haemodynamic) Findings } & \multirow{3}{*}{$\begin{array}{c}\text { Observa- } \\
\text { tion } \\
\text { (yrs) }\end{array}$} & \multirow{3}{*}{ Results } \\
\hline \multicolumn{3}{|c|}{$\begin{array}{c}\text { Cardiac Output } \\
(1 . / \mathrm{min} .)\end{array}$} & \multicolumn{3}{|c|}{$\begin{array}{l}\text { Peak Systolic Gradient } \\
(\mathbf{m m} . \mathbf{H g})\end{array}$} & & \\
\hline Rest & $\mathbf{I}$ & II & Rest & I & II & & \\
\hline - & 8.9 & $13 \cdot 0$ & 0 & 15 & 35 & 3 & Excellent; working full time \\
\hline - & - & - & 一 & 一 & - & 3 & Excellent; working full time \\
\hline$\overline{3 \cdot 4}$ & $\overline{5 \cdot 1}$ & 二 & $\overline{0}$ & $\overline{0}$ & 二 & & $\begin{array}{l}\text { Good; not working } \\
\text { Good; not working }\end{array}$ \\
\hline $4 \cdot 7$ & - & 二 & 0 & - & 二 & $1 \frac{1}{2}$ & Died after $1 \frac{1}{2}$ years in sepsis \\
\hline $\begin{array}{l}\overrightarrow{6 \cdot 8} \\
5 \cdot 4\end{array}$ & $\overline{9 \cdot 2}$ & $\overline{13 \cdot 1}$ & $\overline{20}$ & $\begin{array}{l}\overline{20} \\
18\end{array}$ & $\begin{array}{l}\overline{40} \\
24\end{array}$ & & $\begin{array}{l}\text { Excellent; working full time } \\
\text { Excellent; working full time } \\
\text { Excellent until death from dissociated aortic aneurysm } 2 \mathrm{yrs} 1 \mathrm{mth}\end{array}$ \\
\hline$\overline{6 \cdot 7}$ & $\overline{9 \cdot 3}$ & 二 & $\overline{0}$ & $\frac{1}{0}$ & 二 & $\begin{array}{l}2 \\
2\end{array}$ & $\begin{array}{l}\text { Excellent; working full time } \\
\text { Excellent; working full time }\end{array}$ \\
\hline- & - & $=$ & - & & $\overline{-}$ & 2 & Good; not working \\
\hline $\begin{array}{l}5 \cdot 4 \\
6 \cdot 7\end{array}$ & $\begin{array}{r}10 \cdot 0 \\
9 \cdot 8\end{array}$ & $\begin{array}{l}12 \cdot 8 \\
14 \cdot 2\end{array}$ & $\begin{array}{l}15 \\
30\end{array}$ & $\begin{array}{l}10 \\
42\end{array}$ & $\begin{array}{l}38 \\
45\end{array}$ & $\begin{array}{l}2 \\
2\end{array}$ & $\begin{array}{l}\text { Fair; not working } \\
\text { Excellent; working full time }\end{array}$ \\
\hline $4 \cdot 7$ & $9 \cdot 3$ & 9.8 & 0 & 15 & 20 & & Excellent; working full time \\
\hline $9 \cdot \mathbf{i}$ & $11 \cdot 4$ & $15 \cdot 0$ & 40 & 40 & 55 & $\overline{2}$ & Excellent; not working \\
\hline - & - & - & - & - & - & $\frac{1}{2}$ & Died from left coronary artery emboli \\
\hline - & 一 & 一 & 一 & - & 二 & 2 & Good; not working. Infarction six months post-op. \\
\hline 二 & $=$ & $=$ & 二 & 二 & 二 & 22 months & $\begin{array}{l}\text { Excellent; not working } \\
\text { Excellent: working full time }\end{array}$ \\
\hline 二 & 二 & 二 & 二 & 二 & $\overline{-}$ & 20 months & $\begin{array}{l}\text { Excellent; working full time } \\
\text { Reop. for recurrence, then excellent result without diastolic murmur }\end{array}$ \\
\hline & & & & & & & Heart $430 \mathrm{ml} . / \mathrm{m}^{2}$ \\
\hline
\end{tabular}

In patient 17 myocardial infarction occurred six months after the operation. As he survived the aetiology is unknown. At necropsy no thrombi were found on the ball valve in patients 8 and 16 , nor in patient 20 at re-operation. Such aggregations were found in patient 5 , who died in sepsis.

\section{DISCUSSION}

The rapid decrease in early mortality is striking. There were three late deaths, but the fatal outcome was not related to the function of the ball valve. The occurrence of systemic embolism in patients with a mitral ball valve prosthesis evidently has no counterpart in those in whom an aortic prosthesis has been used. Thrombi on the base of the aortic ball valve have been found only in patients with septicaemia. This difference is probably related to differences in the flow rate.

The hasmodynamic studies show that at rest there was as a rule no significant obstruction to left ventricular outflow. In some patients a high cardiac output was found on exercise, and in these a moderate pressure gradient was registered. This may have been due to an obstructive effect of the prosthesis. However, the role of increased turbulence, due to the high flow rate and the construction of the valve, should be taken into consideration. The size of the prosthesis was no. 11 or larger in our patients with post-operative left heart catheterization. The correlation between the gradient and the size of the prosthesis will have to be studied in a larger series.

With a similar type of aortic ball valve Harken and his co-workers found a peak gradient of 25 $\mathrm{mm}$. $\mathrm{Hg}$ in a pulse duplicator, and in two patients who had been operated upon a mean systolic gradient of 17 and $12 \mathrm{~mm}$. Hg (Harken, Soroff, Taylor, Lefemine, Gupta, Lunzer, and Low, 1961 ; Wagner, Soroff, Fossberg, and Harken, 1963). Starr, Edwards, McCord, and Griswold (1963) found no peak gradient in 11 patients when measured at operation by means of direct left ventricular puncture. In a later study of the same group 10 were investigated six to 12 months after the operation (Bristow, McCord, Starr, Ritzmann, and Griswold, 1964). A peak gradient of between 14 and $30 \mathrm{~mm}$. $\mathrm{Hg}$ was found at rest. In only one did the gradient increase during exercise. However, the work load was probably slight, resulting in only a moderate increase in cardiac output. In five patients with aortic and mitral ball valve prostheses a peak gradient over the aortic valve at follow-up was found in only one $(15 \mathrm{~mm}$. Hg) (Starr, McCord, Wood, Herr, and Edwards, 1964). Judson, Ardaiz, Strach, and Jennings (1964) re-investigated eight patients with the StarrEdwards aortic prosthesis. In five there was no gradient, but in three gradients of 20,25 , and 90 $\mathrm{mm}$. Hg were measured. The highest cardiac index, $4.41 . / \mathrm{min} . / \mathrm{m}^{2}$, was found in a patient with the highest gradient. In another isoproterenol 
infusion increased the gradient from 25 to 75 $\mathrm{mm}$. $\mathrm{Hg}$ while the cardiac index increased from 3.00 to $4.661 . / \mathrm{min} . / \mathrm{m}^{2}$

Significant aortic insufficiency was present only in patient 20 . In some patients a diastolic murmur of aortic insufficiency was heard. Thoracic aortography demonstrated in some of these a slight regurgitation into the left ventricle. This could be physiological if a small amount of contrast is present in early diastole between the ball and the base of the valve. However, the diastolic murmur was heard well after the second aortic sound, which seems to indicate a leak during diastole. Further, if a physiological leak exists this should be demonstrable more constantly. Functional pulmonary valvular insufficiency (Graham-Steell) can be excluded in these patients who have normal pulmonary artery pressures at rest.

The decrease in heart size is one of the most obvious objective signs at follow-up. If cardiomegaly is of long duration myocardial fibrosis is present; and thus in the older age-groups only small reductions in heart size can be expected.

This myocardial factor probably explains why some patients achieved only slight or moderate subjective and objective clinical improvement in spite of a good valve function. The exercise test gives a general idea of the functional status of the patient. The lack of correlation between the post-operative working capacity and the social rehabilitation is of interest. This is partly explained by the long post-operative period of inactivity.

\section{SUMMARY}

More than 100 patients have been operated upon and Starr-Edwards aortic ball valve prostheses have been inserted. The first 20 survivors have been followed for two to three years. Post- $\overrightarrow{\vec{s}}$ operative left heart catheterization has been per- $\bar{O}$ formed in 10 patients and thoracic aortography in twelve.

At rest no gradient or a small gradient over the $\stackrel{\nabla}{\mathbb{D}}$ ball valve was found. With exercise the gradient increased to a maximum of $55 \mathrm{~mm}$. $\mathrm{Hg}$ in this series. Thus there is an obstruction to left $\vec{\circ}$ ventricular outflow, but this is only slight and $\overrightarrow{\vec{\omega}}$ probably has no effect on the end result.

The diastolic murmur of aortic regurgitation $\overrightarrow{\vec{x}}$ was found in some patients. The degree of

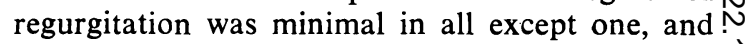
this patient underwent another operation.

The post-operative heart volume was unaltered or decreased in all patients except in the one who 9 had a recurrence of severe regurgitation.

\section{REFERENCES}

Björk, V. O. (1964). Aortic valve replacement. Thorax, 19, 369. Cullhed, I., and Lodin, H. (1963). Aortic valve prosthesis (teflon). Two year follow-up. J. thorac. cardiovasc. Surg., $\rightarrow$ 45, 635 .

Bristow, J. D., McCord, C. W., Starr, A., Ritzmann, L. W., and Griswold, H. E. (1964). Clinical and hemodynamic results of:aortic valvular replacement with a ball-valve prosthesis. Circulation, 29, Suppl., p. 36. [Cardiovas(ular Surgery 1963.]

Cullhed, I. (1964). Aortic Stenosis. Almquist \& Wiksell, Uppsala, Sweden.

Harken, D. E., Soroff, H. S., Taylor, W. J., Lefemine, A. A., Gupta, S. K., Lunzer, S., and Low, H. B. C. (1961). Aortic valve replace-o ment. In K. A. Merendino: Prosthetic Valves for Cardiac (D) Surgery, pp. 508-526. Charles C. Thomas, Springfield, III. Jonsell, S. (1939). A method for the determination of the heart size by $\overrightarrow{\overrightarrow{0}}$
teleroentgenography. Acta radiol. (Stockh.), 20, 325.

Judson, W. E., Ardaiz, J., Strach, T. B. J., and Jennings, R. S. (1964). Postoperative evaluation of prosthetic replacement of aortic and mitral valves. Circulation, 29, Suppl., p. 14.

Larson, R. E., and Kirklin, J. W. (1964). Early and late results of partial and total replacement of the aortic valve with individual teflon cusps. $J$. thorac. cardiovasc. Surg., 47, 720. Starr, A., Edwards, M. L., McCord, C. W., and Griswold, H. E.

— McCord, C. W., Wood, J., Herr, R., and Edwards, M. L. (1964). Surgery for multiple valve disease. Ann. Surg., 160, 596.

Wagner, E., Soroff, H. S., Fossberg, A. M., and Harken, D. E. (1963). Die Verwendung der 'Caged-ball'-Klappe für den totalen: Ersatz der Aorten- und Mitralklappe. Thoraxchirurgie, 10, 331 . O

Wahlund, H. (1948). Determination of the physical working capacity. Acta med. scand., Suppl. 215. 